\title{
An Analysis of Factors Affecting Credit Scoring Performance in SMEs*
}

\section{KOBi'lerde Kredi Derecelendirme Performansını Etkileyen Faktörlerin Analizi}

\author{
Ebru SAYGILI ${ }^{1}$ \\ Arikan Tarik SAYGILI² \\ Gokhan ISIK ${ }^{3}$
}

\author{
https://Orcid No: 0000-0002-0458-8740 \\ https://Orcid No:0000-0002-2013-1695 \\ https://Orcid No:0000-0001-9641-6219
}

\begin{abstract}
In small and medium enterprises (SMEs), both financial and non-financial indicators related to the company and the large shareholder have significant effects on credit scores. This study explores the hybrid nature of SME credit scoring systems by developing an SME credit scoring model with general indicators, financial indicators and intelligence indicators related to the company and the major shareholder. This study is the first to explore the effect of intelligence indicators in credit scoring. It used regression analysis to evaluate real data from 125 SMEs operating in Turkey. Of 17 independent variables, 9 had statistically significant relationships with SME credit scores. The paper includes a comprehensive discussion of the implications of these findings.
\end{abstract}

Keywords: Credit Scoring, Small and Medium Enterprises (SMEs), Multiple Regression, Intelligence Indicators

\section{Introduction}

SMEs are the backbone of the economy in both developed and developing countries. They are small but effective economic units and important building blocks of the wider economy, efficiently producing various products and services as well as inputs of productive factors for larger corporations due to their flexible managerial and manufacturing structures. They particularly contribute to regional development and employment. According to Aksumer (2013), SMEs mean entrepreneurship, innovation and employment.

\begin{abstract}
ÖZET
Küçük ve Orta Ölçekli İşletmeler'de (KOBI) işletme ve işletmenin hakim ortağı ile ilgili finansal ve finansal olmayan göstergelerin kredi notu üzerinde önemli etkisi bulunmaktadır. Bu çalışma, işletme ve hakim ortak ile ilgili genel faktörler, finansal faktörler ve istihbarat faktörlerinin karmasından oluşan KOBi kredi derecelendirme sistemlerini inceleyerek bir model önerisi geliştirmektir. Bu araştırma istihbarat faktörlerinin etkisini araştıran ilk çalışmadır. Regresyon yöntemi ile Türkiye'de faaliyet gösteren 125 KOBi'nin gerçek verileri analiz edilmiştir. Analiz sonuçlarına göre, 17 bağımsız değişkenden 9 tanesi ile KOBi kredi notu arasında istatistiksel olarak anlamlı ilişki vardır. Bu kapsamda analiz sonuçları kapsamlı olarak değerlendirilmiştir.
\end{abstract}

Anahtar Kelimeler: Kredi Derecelendirme, Küçük ve Orta Ölçekli İşletmeler (KOBI), Çoklu Regresyon, İstihbarat Faktörleri

SMEs can offer greater productivity than large scale enterprises compared to the investment needed. They are better at creating marginal employment, promoting more equal income distribution and therefore preventing imbalances in regional development (Ay and Talasli, 2007). Countries that realize the economic importance of SMEs have developed and continuously updated laws, rules and regulations in order to increase SMEs' contributions to the economy. This study evaluates the influences of financial and non-financial factors in determining credit scores. It differs from ot- 
hers in terms of the data set used and its scope. Firstly, it identifies the direct correlation between a credit rating and the factors affecting it, critically through the weighting of factors in the scoring method. Secondly, it examines both financial data and non-financial data. Thirdly, it uses a data set gathered solely from SMEs that play a significant role in Turkey's economy.

Since the 1970s, when the small business ideology started to become more popular worldwide (Muftuoglu, 2002), SMEs have led the market in both developed and developing countries. SMEs play important roles in socio-economic development, employment and fair distribution of income (Akgemici, 2001). In the United States, for example, SMEs account for $97.2 \%$ of all companies, providing jobs to $50.4 \%$ of the US work force and producing $36.2 \%$ of US GDP and $32 \%$ of exports (Cansiz, 2008). In Turkey, 99.8\% of companies are SMEs, providing $75.8 \%$ of employment and $54.5 \%$ of the payroll in the Turkish economy in 2012. Moreover, 54.5\% of capital investment was made by SMEs while they generated $63.3 \%$ of income and $54.2 \%$ of GNP in 2012. Turkish SMEs generated around $59.2 \%$ of the country's export income in 2013, with $91.5 \%$ of this coming from domestically-produced tangible products.

Yet despite playing very important social and economic roles, SMEs tend to have certain weaknesses, such as managerial shortcomings, inadequate labor qualifications and skills, inadequate technological investment, meager marketing operations and bargaining power compared to larger corporations. However, their main weakness is inadequate financing alternatives, which is believed to be the main source of the other weaknesses mentioned above. Thus, developing a financial system that offers sufficient alternatives to SMEs would help solve the other problems faced by SMEs. Equity financing is the most common option for SMEs, especially in countries where the financial system favors larger corporations. However, because SME owners' capital investments are usually far from being sufficient, securities exchange markets have been developed to provide an alternative source financing, whereby SMEs can obtain capital by issuing securities. Although there are successful examples of SME securities markets, such as NASDAQ in the USA, this option is not very feasible for most SMEs, whose owners lack adequate financial skills and knowledge about basic concepts and procedures, such as determining type, price and timing of securities to be issued. Consequently, SMEs remain unable to benefit from securities exchange markets. The optimal and most preferred alternative for SME financing is believed to be bank credits. However, SMEs receive only a very small share of bank credits issued to corporations. In addition, credit limits for SMEs are usually lower than those available to larger corporations, higher interest rates are charged and banks require higher collateral and/or impose additional terms for granting loans to SMEs.

From a credit institution's perspective, it is quite rational to favor larger corporations since they are financially less risky and more able to repay their debts. Nevertheless, a financial system is needed to make it easier for SMEs to obtain sufficient funds. The first step would be to implement an appropriate credit scoring system for SMEs, meaning a system to help financial analysts evaluate financial risks and accurately determine the limit, duration and cost of credit. Such a system would also benefit credit institutions by enabling them to lower the risk of defaults and offer more loans, thereby increasing bank revenues. At the same time, SMEs would benefit from a financial system in which credit institutions feel less hesitant in granting loans with more favorable terms due to a more reliable credit scoring system.

Credit scoring models are the most widely used systems by credit institutions to manage credit processes reliably. Quantitative and qualitative information about the customer, as well as the judgement and experience of the rating analyst, are important factors for evaluating applicants' creditworthiness (Bluhm et al., 2003). The scoring system is dynamic, in that the credit score is updated based on changing conditions and new financial data, such as periodical financial statements. Generally, the main aims of the scoring procedures of credit institutions are to measure risk levels of companies and minimize problems in the credit relationships with their customers. Credit scores should help to appraise each applicant company accurately so that the analyst can prepare suitable credit plans and strategies to apply to companies with different risk levels and financial constraints. Thus, credits for lower risk groups will have lower interest rates and other favorable terms. This allows credit institutions to manage their capital more efficiently and effectively while contributing to the overall economy by providing sufficient loans to a greater proportion of enterprises in need. Furthermore, an efficient credit scoring system allows financial resources to be allocated at lower cost, enables analysts to determine credit limits and identify problematic loans (Sirvan, 2004). Credit 
scoring is a statistical model that incorporates both financial and non-financial measures. Scoring models can include many different financial and non-financial criteria depending on credit institution's credit policies and annual financial targets in consideration with the legal framework and economic context. Companies must be aware of these multiple criteria and their weightings in order to improve the accuracy of their eligibility and credit scores.

This paper is organized as follows. The second section reviews the research stream on credit scoring before proposing a new credit scoring model for SMEs. The third section uses linear regression to analyze the relationship between credit scoring performance and financial and non-financial data from 125 SMEs in Turkey. The fourth section identifies and discusses the influences of financial and nonfinancial independent variables on credit scoring.

\section{Literature Review}

Credit scoring involves various techniques and decision-making models that aim to assist creditors guarantee repayment of the principle and interest of credit, as seen in Table 1. These techniques are used to accurately determine whether to grant the loan and, if so, what terms and conditions to apply, including duration, credit limit and interest rate. The scoring system is used for forming a reliable basis for credit risk management as well as the accumulation of historical data for the following periods (Babuscu, 2005). Scoring enables decisions to be more objective and minimizes the subjective evaluations of bank employees through the use of identical, standard procedures. This in turn increases the confidence of both credit institutions and applicants in the decisions.

The majority of studies of credit scoring aim to develop statistical models for banks. These can be placed in two categories, corporate credit scoring and consumer credit scoring, as summarized in Table 1. Studies of corporate credit scoring have proposed various prediction models that include variables such as credit score (Emel et al., 2003; Sezgin, 2006; Min and Lee 2008; Bingol, 2009), profit or loss (Vurur, 2009), credit risk (Zhang et al., 2013), probability of default and lending attitude (Ono, 2014), and credit risk management (Belas et al., 2017). Several models use financial ratios (Emel et al., 2003; Min and Lee, 2008; Bingol, 2008, Vurur, 2009, Altman et al., 2018) while some of use both financial and non-financial indicators (Sezgin, 2006; Zhang et al., 2013; Ono et al., 2014). On the other hand, consumer credit scoring studies focus on credit performance (Marshall et al., 2010; Louzada et al., 2012), value at risk (Jacobson and Roszbach, 2003), probability of default (Dinh and Kleimeier, 2007), loan quality (Abdou, 2009) and credit decision (Bekhet and Eletter, 2014) while considering financial and non-financial indicators during the scoring process.

Emel, et al. (2003) conducted one of the pioneering studies of corporate credit scoring methodology in Turkey. They used Data Envelopment Analysis (DEA) to measure overall company performance by a single credibility score. The financial ratios of 82 manufacturing companies that applied for loans from one Turkish commercial bank were used in this study. While credit score was the dependent variable, 46 ratios related to bank loans, fixed assets, financial leverage, profitability, liquidity, liability term structure, sales and costs aspects were the independent variables. They concluded that firms with higher credit scores have higher liquidity, lower bank loans, higher capital adequacy and a better balance between their equity and fixed assets. Min \& Lee (2008) conducted a study in the Republic of Korea, using similar dependent variables and methodology. However, their independent variables were financial ratios related to growth, liquidity, operational efficiency, profitability, productivity and cost structure. They also evaluated the reliability of DEA results using real bankruptcy cases from 103 firms. Sezgin (2006) adopted the Internal Rating Based Approach proposed by New Basel Capital Accord (BIS, 2001) to evaluate the performance of four different models in order to improve internal credit rating process in banks, using validation techniques suggested by the Basel Committee. The dependent variable was credit rating while there were 16 financial and 13 non-financial indicators as independent variables for a sample of 1,649 loan applications to a Turkish bank, including 61 defaulted and 1,578 non-defaulted firms. The study compared the credit scores of defaulted and non-defaulted companies by applying logistic regression to financial data gathered from KOSGEB loan records. Zhang et al. (2013) analyzed the factors affecting the credit risk of the high-tech enterprises in China using the Cox Model, and concluded that current ratio, accounts receivable turnover ratio, total asset turnover ratio and return equity ratio significantly influence the credit risk of high-tech enterprises. More specifically, the stronger that a high-tech enterprise's independent innovation ability is, the lower its credit risk will be. However, they found that regional factors 
have a relatively limited impact on the credit risk of high-tech enterprises. Belas et al. (2017) searched the dependence between the entrepreneur's ability to manage the credit risk in their company effectively and their knowledge of the corporate capital.

Several studies have investigated SME credit scoring in the first group. Bingol (2009) developed a credit evaluation method to determine the credit scores of Turkish SMEs operating in the textile sector, using 27 financial ratios from of 1,497 SMEs to develop three statistical models from which particular correlations were gathered. The results indicated that firms must emphasize transparency while producing financial statements and make the required technological investments. Vurur (2009) developed a forecasting model for SMEs to determine the probability of financial failure. Altman et al. (2018) developed a new innovative model to assess SMEs' creditworthiness and we test it on the companies that have issued mini-bonds from this market's inception in 2013 to 2015.
The second category of studies concerns consumer credit scoring. Jacobson and Roszbach (2003) proposed two models for a bank's decision to grant a consumer loan and to measure the probability of default. They used a Monte-Carlo simulation with the bivariate probit model to obtain a Value at Risk (VAR) measure for their sample loan portfolio. Dinh and Kleimeier (2007) developed a credit scoring model with logistic regression for Vietnamese retail loans to demonstrate how such a model can enable a bank to achieve its strategic objectives. Other researchers have assessed the use of credit scoring models in the context of transactional versus relationship lending. Ono et al. (2014) reported rather mixed findings from their study conducted in Japan. They concluded that the ex-post probability of an SME defaulting on a Small Business Credit Scoring (SBCS) loan significantly increased if the loan was obtained through a transactional lender. They attributed this to cultural factors that affect lenders' and borrowers' relationships and attitudes. 


\begin{tabular}{|c|c|c|c|c|c|c|c|c|c|c|c|c|c|c|c|}
\hline 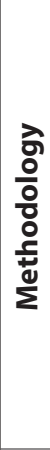 & 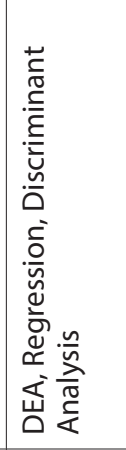 & 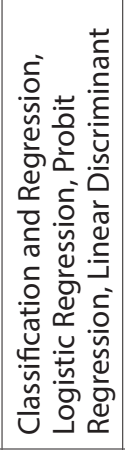 & 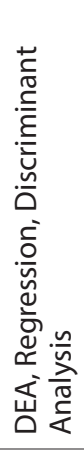 & 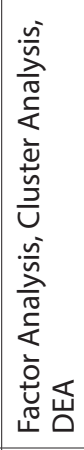 & 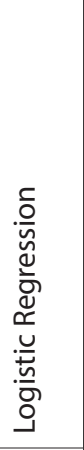 & 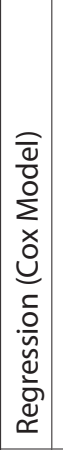 & 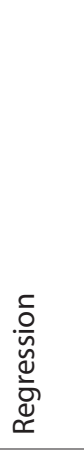 & 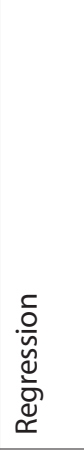 & 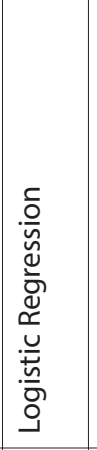 & $\begin{array}{l}\frac{\bar{d}}{0} \\
\frac{0}{0} \\
\frac{1}{0} \\
\frac{0}{0} \\
\frac{0}{2}\end{array}$ & 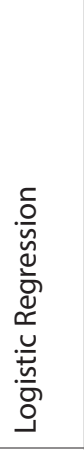 & 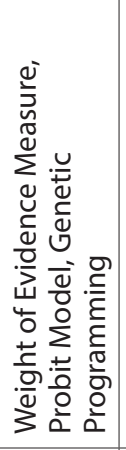 & $\begin{array}{l}\frac{n}{\omega} \\
\frac{0}{0} \\
\sum^{\frac{0}{2}} \\
\frac{0}{0} \\
\frac{0}{0}\end{array}$ & 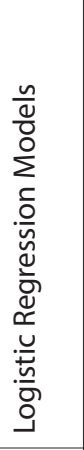 & 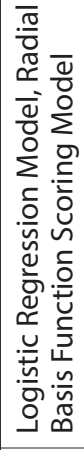 \\
\hline 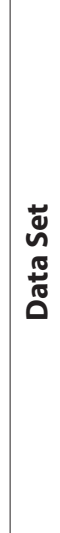 & 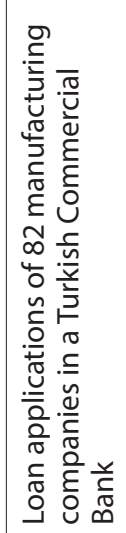 & 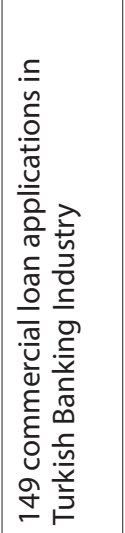 & 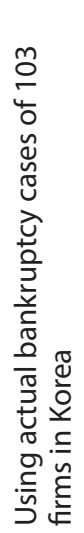 & 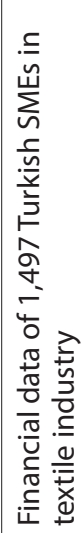 & 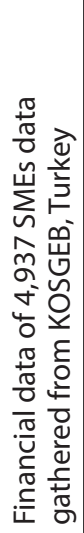 & 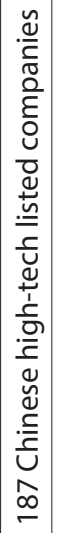 & 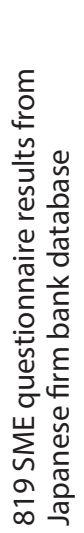 & 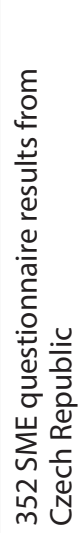 & 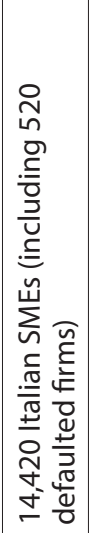 & 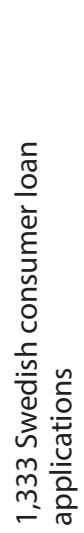 & 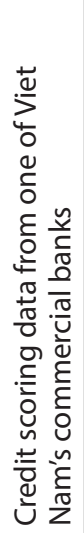 & 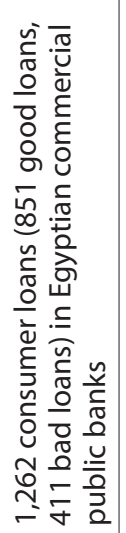 & 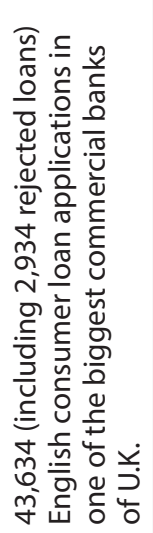 & 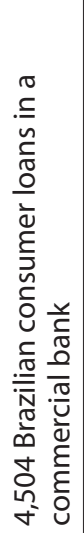 & 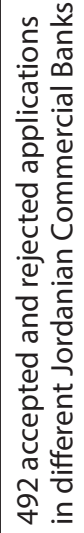 \\
\hline
\end{tabular}

\begin{tabular}{|c|c|c|c|c|c|c|c|c|c|c|c|c|c|c|c|}
\hline 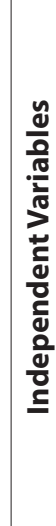 & 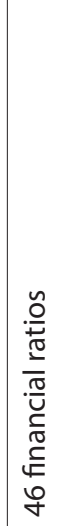 & 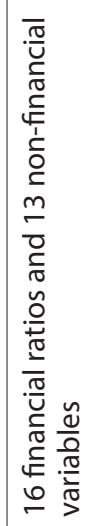 & 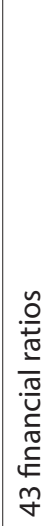 & 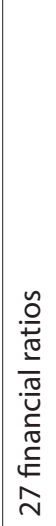 & 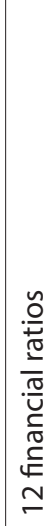 & 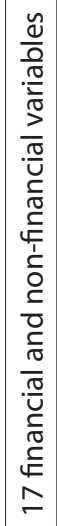 & 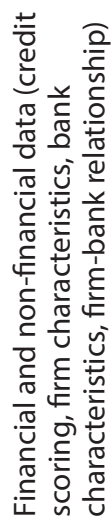 & 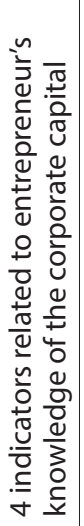 & 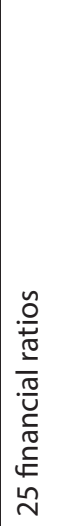 & 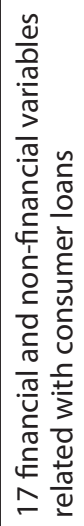 & 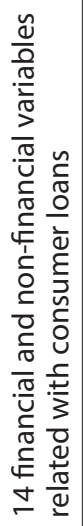 & 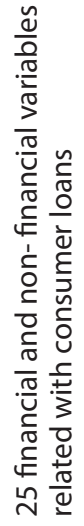 & 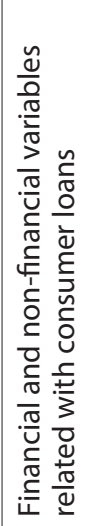 & 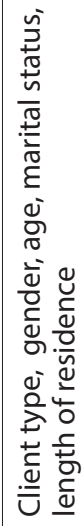 & 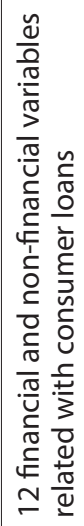 \\
\hline
\end{tabular}

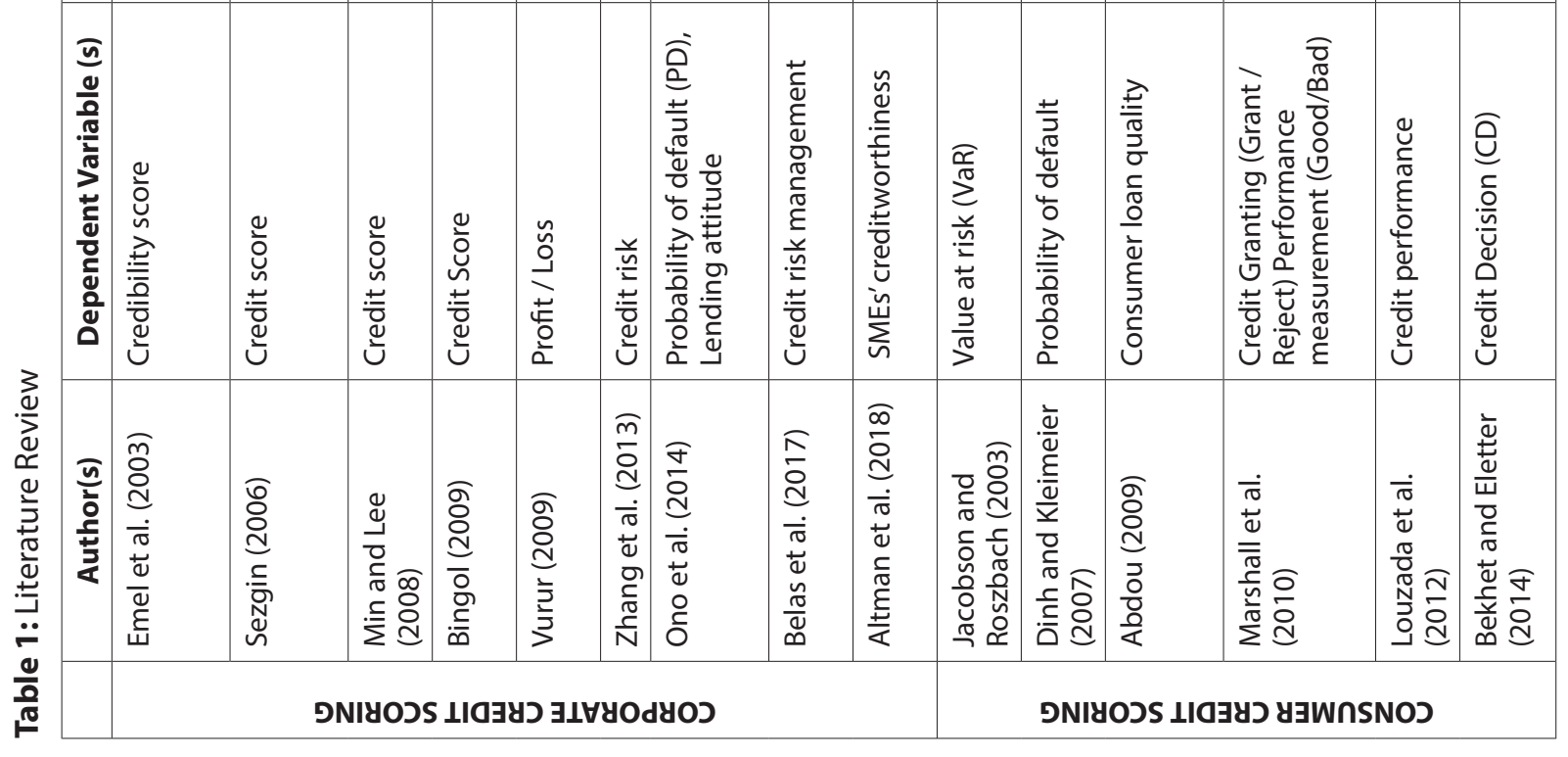


Abdou (2009) developed and evaluated three different models to examine the quality of 1,262 personal loans (851 good loans, 411 bad loans) from Egyptian commercial public sector banks. They concluded that the Weight of Evidence measure (WOE) was the best model. Marshall et al. (2010) investigated the effect of sample selection bias on the probability of default for retail bank customers by applying a standard probit model to consumer loan data from one of the UK's largest commercial banks. They concluded that sample selection bias can be overcome by estimating the credit granting decision and performance assessing processes simultaneously. Other studies were similar to credit rating examinations. Louzada, et al. (2012) analyzed the performance of a naive logistic regression model and a logistic regression with a state dependent sample selection model applied to simulated results. Other studies evaluated credit scoring model's performance on a data set extracted from a Brazilian bank portfolio. For instance, Bekhet \& Eletter (2014) proposed two credit scoring models using data mining techniques to support Jordanian commercial banks' loan decisions. They reported that Logistic Regression is more accurate than Radial Basis Function and warned that extending credit to customers with high probability of default may lead to financial distress.

Banks collect a considerable amount of information during the credit scoring process. SME credit scoring therefore has a hybrid nature that draws on financial and non-financial criteria about both the company and the major shareholder (main partner). Among the few studies of SME credit scoring, Ono et al. (2014) used financial and non-financial variables together. This current study is the first to analyze both financial and non-financial indicators about both companies and major shareholders in Turkey The indicators in the model are discussed in the next section.

\section{Research Design and Empirical Predictions}

This study evaluates the correlations between credit rating and multiple financial and non-financial data. It therefore applies multivariate (multiple) regression analysis as this is a highly reliable method for measuring correlations between multiple variables (Higgins, 2005; Rencher 2002; Joseph et al., 2010,). SPSS version 22 was used to conduct the regression analysis.

\subsection{Dataset}

The dataset for this study was obtained from one of the credit institutions operating in Turkey's financial market. The data set was gathered from credit scoring evaluations between 2012 and 2016, during which the credit scoring policy of the credit institution was stable. Data were included from 125 SMEs operating in Turkey with 0 to 25 million TL annual revenues. Companies of group firms were excluded from the research.

\subsection{Variables and Descriptive Statistics}

The proposed model, presented in Table 2, includes general indicators, financial indicators and intelligence indicators. General indicators are information about the company and major shareholder while financial indicators are the company's financial ratios. The present model also includes intelligence indicators about both the major shareholder and the company, which is another new contribution to the relevant literature. There were 9 general information variables for the company and major shareholder, 5 financial information variables and 3 intelligence information variables. Table 3 lists the variables and their codes.

We used the following empirical model:

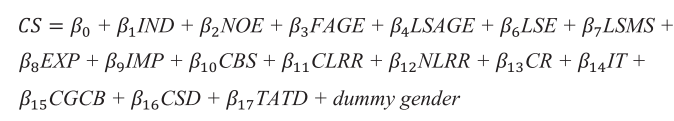

Table 2: SME Credit Scoring Model

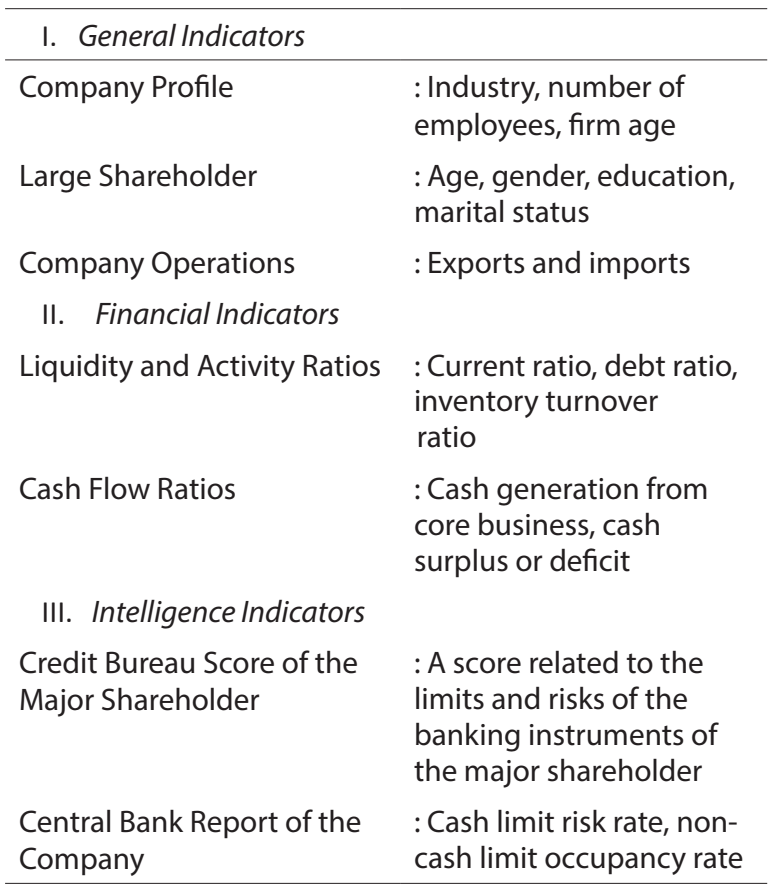


Table 3: List of Predictor Variables in the Analysis

\begin{tabular}{|c|c|c|}
\hline & Variables & \\
\hline CS & Credit Score & \\
\hline IND & Industry & : $X=1$ : merchandise, 0 : manufacturing \\
\hline NOE & Number of Employees & \\
\hline FAGE & Firm Age & \\
\hline LSAGE & Major Shareholder Age & \\
\hline LSG & Major Shareholder Gender Dummy & $: X=1:$ male, $0:$ female \\
\hline LSE & Major Shareholder Education & : $X=1$ : high school, 2: bachelor, 3: MSc. \\
\hline LSMS & Major Shareholder Marital Status & $: X=1:$ married, 0 : single \\
\hline IMP & Import Operations & $: X=1:$ Yes, $0:$ No \\
\hline EXP & Export Operations & $: X=1: Y e s, 0:$ No \\
\hline CBS & Major Shareholder Credit Bureau Score & \\
\hline$C L R R$ & Cash Limit Risk Rate of the Company & \\
\hline$N L R R$ & Non-Cash Limit Risk Rate of the Company & \\
\hline$C R$ & Current Rate & \\
\hline IT & Inventory Turnover Date & \\
\hline$C G C B$ & Cash Generation from Core Business Activities & $: X=1: Y e s, 0:$ No \\
\hline$C S D$ & Cash Surplus or Deficit & $: X=1:$ Yes, $0:$ No \\
\hline TATD & Debt Ratio & \\
\hline
\end{tabular}

\subsubsection{Primary Dependent Variable}

CS - Credit Score: The credit scores in the dataset were chosen from 125 SMEs evaluated by a Turkish credit institution's scoring system between 2012 and 2016. In this system, the best credit performance is scored as 1, meaning that credit performance worsens as the rating score increases. Companies with scores of 1 to 12 received the requested credit while companies with scores of 13 to 15 received $60 \%$ percent of the requested credit. Requests from companies with credit scores over 16 were rejected. Both the accepted and rejected applications were included in the analysis so $16 \%$ of the data set represents rejected applications.

\subsubsection{Primary Independent Variables}

\section{General indicators}

IND - This study analyzed SMEs from merchandising and manufacturing industries. $50.4 \%$ of the companies were merchandising companies.

NOE - Number of Employees: NOE was expected to have a positive relation with CS. Companies with more employees were predicted to have better credit scores.

FAGE - Firm Age: The variable represents the years since the SME's establishment. FAGE was expected to have a positive relation with CS. Companies operating for longer were predicted to have better credit scores.
LSAGE - Major Shareholder Age: LSAGE was predicted to have a positive relation with CS.

LSG - Major Shareholder Gender: $90 \%$ of the companies had male large shareholders.

LSE - Major Shareholder Education: The major shareholders of $47 \%$ of SMEs had bachelor degree or higher. LSE was expected to have a positive relation with CS.

LSMS - Major Shareholder Marital Status: 93\% of major shareholders were married.

IMP - Import: This variable indicates whether the SMEs have import operations or not. IMP was expected to have a negative relation with CS.

EXP- Export: This variable indicates whether the SMEs had exports or not. EXP was expected to have a positive relation with CS. Only $10 \%$ of the companies had export operations.

\section{Financial Indicators}

CR - Current Ratio: As a liquidity ratio, this shows each company's ability to pay back its short-term debts. It is calculated as Current Assets / Current Liabilities. Data was provided from year-end balance sheets. CR was expected to be positively associated with CS. 
IT- Inventory Turnover in Days: This financial ratio indicates the number of days that goods remain in inventory before sale, calculated as (Average Inventory / 2) / (Cost of sales / 360). IT was expected to have a negative relation with $\mathrm{CS}$.

TATD - Debt Ratio: This indicates the ratio of total assets to total debt, including leasing and factoring debts too, calculated as Total Assets / Total Debts. TATD was expected to have a positive relation with CS.

CGCB - Cash Generation from Core Business activities: CGCB was expected to have a positive relation with CS.

CSD - Cash Surplus or Deficit:The variable measures cash surplus or deficit at the end of the operating year, calculated as Short Term Financial Debts / Total Cash Deficit. CSD was expected to have a positive relation with CS. $78 \%$ of the companies had a cash deficit.

\section{Intelligence Indicators}

CBS-Credit Bureau Score of Large Shareholder:The Turkish Credit Bureau is a credit database corporation with a founding membership of 11 Turkish banks that collects all Turkish citizens' individual credit data to generate a credit score, called CBS, that depends on their payment performances. Turkish banks commonly use CBS scores, which can vary between 0 and 1,900 ( 0 is the worst score), to evaluate an individual's credibility. The variable here refers to the CBS score of the major shareholder, which was expected to have a positive relation with CS.

CLRR - Cash Limit Risk Rate: This variable, obtained from central bank reports, refers to a company's percentage of total cash limit occupancy in all banks without distinction of maturity and currency. Factoring and leasing debts were excluded. CLRR was expected to have a negative relation with CS.

NLRR - Company's Non-Cash Limit Occupancy Rate: The variable, obtained from central bank reports, refers to a company's percentage of total non-cash limit occupancy in all banks without distinction of maturity and currency. Factoring and leasing debts were excluded. NLRR was expected to have a negative relation with $\mathrm{CS}$.

Descriptive statistics for the data are presented in Table 4.

\section{Multivariate Test Results and Discussion}

Several assumptions must be met before conducting a multiple regression. First, there should be one dependent variable measured at the continuous level. Credit Score (CS) was a continuous variable. Second, there should be two or more independent variables that are measured at continuous or nominal level. In this study, the independent variables were all measured at continuous or nominal level, as shown in Table 5.

Table 4: Descriptive Statistics

\begin{tabular}{lrrrrr}
\hline & $\mathrm{N}$ & Minimum & Maximum & Mean & Std. Deviation \\
\hline CS & 125 & 1.00 & 21.00 & 10.2320 & 4.63878 \\
IND & 125 & 0.00 & 1.00 & 0.4640 & 0.50071 \\
NOE & 125 & 1.00 & 200.00 & 22.8960 & 31.37053 \\
FAGE & 125 & 1.00 & 44.00 & 10.3760 & 8.08490 \\
LSAGE & 125 & 24.00 & 76.00 & 46.2400 & 11.23675 \\
LSG & 125 & 0.00 & 1.00 & 0.960 & 0.29578 \\
LSE & 125 & 1.00 & 3.00 & 2.0760 & 0.50264 \\
LSMS & 125 & 0.00 & 1.00 & 0.9840 & 0.93657 \\
IMP & 125 & 0.00 & 1.00 & 0.9360 & 0.24574 \\
EXP & 125 & 0.00 & 1.00 & 0.9680 & 0.17671 \\
CBS & 125 & 1.00 & 1900.00 & 1413.7360 & 368.24019 \\
CLRR & 125 & 0.00 & 0.96 & 0.3886 & 0.23722 \\
NLRR & 125 & 0.01 & 0.89 & 0.3530 & 0.20739 \\
CR & 125 & 0.05 & 9.28 & 1.3878 & 1.10951 \\
IT & 125 & 5.00 & 1344.00 & 154.3680 & 1190.31861 \\
CGCB & 125 & 0.10 & 1.00 & 0.7120 & 0.45465 \\
CSD & 125 & 0.00 & 1.00 & 0.2400 & 0.42880 \\
TATD & 125 & 0.57 & 9.82 & 0.4359 & 1.17419 \\
\hline
\end{tabular}


Table 5: Measurement Levels of Independent Variables

\begin{tabular}{ll}
\hline $\begin{array}{l}\text { Independent Variables Measured at } \\
\text { Continuous Level }\end{array}$ & Independent Variables Measured at Nominal Level \\
\hline Large Shareholder Credit Bureau Score (CBS) & Industry (IND) \\
Number of Employees (NOE) & Large Shareholder Gender (LSG) \\
Firm Age (FAGE) & Large Shareholder Education (LSE) \\
Large Shareholder Age (LSAGE) & Large Shareholder Marital Status (LSMS) \\
Cash Limit Risk Rate of the Company (CLRR) & Exports (EXP) \\
Non-Cash Limit Risk Rate of the Company (NLRR) & Imports (IMP) \\
Current Rate (CR) & Cash Generation (CGCB) \\
Inventory Turnover Date (IT) & Cash Surplus or Deficit (CSD) \\
Debt Ratio (TATD) & \\
\hline
\end{tabular}

Third, there should be independence of observations, which can be assessed using the Durbin-Watson statistic. This statistic can range from 0 to 4 , with approximately 2 indicating that there is no correlation between residuals. The Durbin-Watson statistics for this analysis, presented in Table 6, was 1.877 which indicates there was independence of residuals.

Fourth, if two or more variables are highly correlated then multicollinearity occurs. There are two stages in identifying multicollinearity: inspection of correlation coefficients between independent variables and Tolerance / VIF values. The correlations presented in Table 6 show that all values are less than the threshold of .7. Tolerance and VIF values are given in Table 6. Tolerance values less than 0.1 and VIF values greater than indicates a potential collinearity problem. However, all Tolerance values were greater than 0.1 so there was no collinearity problem.

Fifth, there certain data points may be classified as outliers from the perspective of fitting a multiple regression model as they are generally detrimental to the fit or generalization of the regression equation. This study selected the Casewise diagnostics option in SPSS to use unstandardized residuals. If all cases have standardized residuals less than +3 and more than -3 , this table will not be produced as part of SPSS statistics output. In this study, SPSS did not produce Casewise Diagnostics, indicating that all residuals were standardized.

The $R$ value in Table 6 measures the strength of the linear association between variables and indicates the goodness of the model fit with a value from 0 to 1. Higher values indicate a stronger linear association. In this study, $R$ was 0.780 , indicating a strong level of association. The coefficient $R^{2}$ measures the proportion of variance in the dependent variable explained by the independent variables while adjusted $R^{2}$ corrects for positive bias to provide the value expected in the population. In Table 6, $R^{2}$ was 0.609 whereas adjusted $R^{2}$ was 0.546 . That is, $R^{2}$ for the overall model was $60.9 \%$ and adjusted $R^{2}$ was $54.6 \%$.

The statistical significance of the overall model is presented in the 'Sig.' column of the Table 6 . A value of .000 indicates that $p<0.05$, meaning that the result is statistically significant. The coefficients and significance levels of all independent variables are presented in Table 6, which shows that nine independent variables in the multiple regression had significant correlations with dependent variable, credit score: NOE, FAGE, LSAGE, EXP, CLRR, CR, CGCB, CBS and CSD. All of them, except CLRR, have negative coefficients, which means they lower the credit score. The best credit performance is scored as 1, so credit performance gets better as the rating score decreases. Hence, they have a positive impact on the credit scoring performance.

Among the nine general indicators, four variables (NOE, FAGE, LSAGE and EXP) had statistically significant negative relationships with credit scores. The results of the analysis confirmed that non-financial factors are important and should be taken into consideration. As the number of employees, firm age, large shareholder age and exports increase, credit score decreases which is good for the company. SMEs generally run their operations with fewer employees due to cost advantages and/or constraints. However, this can cause heavy workload, jurisdiction uncertainty and interruption of operations. The number of employees (NOE) is therefore an important indicator considered by credit institutions, and credit scoring systems are designed to assign higher credit scores to companies 
with more employees. SME directors should plan their employee requirements realistically and hire the optimal number of employees. The experience that comes over time and from hard work is another crucial element for success. Especially in developing countries, which have more uncertain environments, industry experience becomes more significant. Credit institutions therefore incorporate experience into their credit scoring systems by assigning higher credit scores for factors as major shareholder's age (LSAGE) and firm age (FAGE) increase. Export operations (EXP) can benefit a company as an indicator of sound marketing operations, high quality and demanded products, and geographically dispersed market shares. It is also perceived as a positive indicator due to advantageous exchange rates for SMEs, especially in developing countries.

Table 6: Statistical Results of the Analysis

Model Summary ${ }^{b}$

\begin{tabular}{cccccc}
\hline Model & $\mathrm{R}$ & R Square & Adjusted R Square & Std. Error of the Estimate & Durbin-Watson \\
\hline 1 & $.780^{\mathrm{a}}$ & .609 & .546 & 3.124 & 1.877 \\
\hline
\end{tabular}

a. Predictors: (Constant), TATD, NLRR, LSMS, LSG, EXP, FAGE, IND, LSE, CSD, CR, IT, CBS, NOE, IMP, LSAGE, CLRR, CGCB

b. Dependent Variable: CS

Coefficients $^{\mathrm{a}}$

\begin{tabular}{|c|c|c|c|c|c|c|c|c|c|}
\hline \multirow[b]{2}{*}{ Model } & \multicolumn{2}{|c|}{$\begin{array}{l}\text { Unstandardized } \\
\text { Coefficients }\end{array}$} & \multirow[b]{2}{*}{$\mathrm{t}$} & \multirow[b]{2}{*}{ Sig. } & \multicolumn{3}{|c|}{ Correlations } & \multicolumn{2}{|c|}{$\begin{array}{l}\text { Collinearity } \\
\text { Statistics }\end{array}$} \\
\hline & $\mathrm{B}$ & Std. Error & & & Zero-order & Partial & Part & Tolerance & VIF \\
\hline (Constant) & 29.992 & 3.286 & 9.128 & $.000^{* * *}$ & & & & & \\
\hline IND & -.425 & .620 & -.685 & .495 & -.175 & -.066 & -.041 & .819 & 1.221 \\
\hline NOE & -.036 & .010 & -3.669 & $.000^{* * *}$ & -.255 & -.334 & -.222 & .843 & 1.187 \\
\hline FAGE & -.116 & .037 & -3.117 & $.002^{* * * *}$ & -.373 & -.289 & -.189 & .866 & 1.155 \\
\hline LSAGE & -.052 & .028 & -1.885 & $.045^{* * *}$ & -.343 & -.179 & -.114 & .804 & 1.244 \\
\hline LSG & .351 & 1.054 & .333 & .740 & -.005 & .032 & .020 & .810 & 1.235 \\
\hline LSE & -.691 & .612 & -1.129 & .261 & -.034 & -.109 & -.068 & .832 & 1.202 \\
\hline LSMS & -.256 & .308 & -.830 & .408 & -.064 & -.080 & -.050 & .947 & 1.056 \\
\hline IMP & .064 & 1.254 & .051 & .959 & .070 & .005 & .003 & .830 & 1.205 \\
\hline EXP & -3.579 & 1.742 & -2.055 & $.042^{* * *}$ & -.158 & -.195 & -.124 & .831 & 1.204 \\
\hline CBS & -.005 & .001 & -6.233 & $.000^{* * * *}$ & -.557 & -.516 & -.377 & .823 & 1.216 \\
\hline CLRR & 2.862 & 1.377 & 2.078 & $.040^{* * *}$ & .246 & .197 & .126 & .738 & 1.356 \\
\hline NLRR & .000 & 1.472 & .000 & 1.000 & .050 & .000 & .000 & .844 & 1.185 \\
\hline CR & -.745 & .271 & -2.745 & $.007^{* * *}$ & -.217 & -.256 & -.166 & .868 & 1.151 \\
\hline IT & -9.362 & .000 & -.370 & .712 & .032 & -.036 & -.022 & .867 & 1.153 \\
\hline CGCB & -2.028 & .813 & -2.496 & $.014^{* * *}$ & .082 & -.235 & -.151 & .577 & 1.734 \\
\hline CSD & -3.361 & .843 & -3.987 & $.000^{* * *}$ & -.276 & -.360 & -.241 & .603 & 1.660 \\
\hline TATD & -.291 & .257 & -1.134 & .259 & -.233 & -.109 & -.069 & .867 & 1.153 \\
\hline
\end{tabular}

aDependent Variable: CS

${ }^{* * *}$ Significant at $1 \%$ level

ANOVAa Results

\begin{tabular}{cccccc}
\hline & Model & Sum of Squares & Mean Square & F & Sig. \\
\hline 1 & Regression & 1623.922 & 95.525 & 9.787 & $.000^{\mathrm{b}}$ \\
& Residual & 1044.350 & 9.760 & & \\
& Total & 2668.272 & & & \\
\hline
\end{tabular}

a. Dependent Variable: CS

b. Predictors: (Constant), TATD, NLRR, LSMS, LSG, EXP, FAGE, IND, LSE, CSD, CR, IT, KKB, NOE, IMP, LSAGE, CLRR, CGCB 
Of the five financial indicators, three variables current ratio $(\mathrm{CR})$, cash generation from core business activities (CGCB) and cash surplus or deficit (CSD) had statistically significant negative relationships with credit scores. As the current ratio, cash generation from core business activities and cash surplus increase, credit score decreases which is advantageous for the company. Because lowest credit score means the best performance. Among the financial factors, liquidity is an important performance measurement and current ratio (CR) has a positive effect on credit scoring. The liquid assets of company should be more than shortterm liabilities in the balance sheet. The company needs to consider networking capital levels and future cash flows. It should not make huge investments on assets that cannot be converted into cash easily unless it is absolutely necessary and feasible. The income obtained from non-core business activities (CGCB) is considered as a permanent source of funds and has an much impact on credit scoring process. Company cash surplus or deficit (CSD) shows that the company has the financial power to fulfill its liabilities. This is especially significant for credit institutions in evaluating credit applications for long-term projects and determining permanent credit limits.

Of the two intelligence variables, Turkish Credit Bureau Score of the large shareholder (CBS) had statistically significant negative relationship and cash limit risk rate (CLRR) had a statistically significant positive relationship with credit scores. As Credit Bureau Score increases credit score decreases which is advantageous for the company. Currently the highest CBS score is 1,900 and the lowest score is zero. Credit should not be seen as the main source of company financing. Rather, the real financing requirements should be determined and the borrowing structure should be organized accordingly. Shareholders' paying performance (CBS) is one of the most significant evaluation criteria, yet generally ignored by companies. In most cases, shareholders have a sense that their personal credibility and the company's credibility are evaluated separately. However, a legal entity's morality is primarily measured through the natural entity's morality. Intelligence variables credit indicate that SMEs should plan their borrowing strategy very carefully and properly and not use cash credit (CLRR) up to their full limit. As the cash limit risk rate (CLRR) increases credit score increases which means a lower performance.

\section{Conclusion}

SMEs are very important for the economy of both developed and developing countries while credit institutions are the most important elements of financial systems by providing the funds that enterprises need to run their operations effectively. Thus, in any country, a healthy economy requires an effective relationship between SMEs and credit institutions. As SME's credit demands increase, the capital supply available should increase to ensure the economy operates effectively and efficiently. Well-designed and diligently applied credit scoring systems are therefore essential for enabling credit institutions to allocate their resources to deserving businesses while minimizing the risk of credit defaults. It is also crucial for SMEs to understand the factors considered in credit applications in order to prepare so that their funding applications are accepted and they gain funds under better terms and conditions.

Recent technological improvements have helped credit scoring systems become the most commonly used models by credit institutions. These systems help creditors to categorize their customers, track their risks effectively and determine credit-related issues, such as credit price and credit policies appropriately. Various credit scoring systems have been developed. Hybrid credit scoring systems, which evaluate performance of the company and the major shareholder simultaneously using both financial and non-financial indicators, seem to suit the best credit scoring method for SMEs. Accordingly, this study used a credit scoring system with financial and non-financial variables of both the enterprise and major shareholder. A data set including financial and non-financial factors was formed and evaluation was performed on real SME data. The model evaluated the predictive power of 17 indicators related to general information, financial information and intelligence information about the company and the major shareholder in order to determine which financial or non-financial factors significantly influence the credit score. This study is the first to explore the effect of intelligence indicators on credit scoring.

Statistical results indicated that nine financial and non-financial variables affected the credit rating. These results indicate important issues about SME scoring systems. Non-financial factors like number of employees, firm age, major shareholder age and export operations play a major role in credibility evaluation. In most bankruptcy cases, financial indicators do not give any early warning sign. However, 
a firm's organizational and operational weaknesses, which are ignored in most credit scoring processes used by banks, cause serious problems leading to credit default. In developing countries, SMEs generally ignore transparency principles by failing to disclose accurate data in their financial statements for analysis, mainly due to tax avoidance considerations. Such companies usually have non-invoiced sales and unregistered employees. Additionally, shareholders' personal expenses are recorded as if they are company expenses to reduce taxable income and pay lower taxes. However, manipulating accounting records to minimize revenues and maximize expenses, reducing profits and arranging organizational structure data to show fewer employees makes the firm appear smaller than it actually is, which disadvantages it during credit applications. Since credit institutions cannot measure these companies' real financial performance accurately, the company ultimately gets worse credit ratings. Liquidity is an important performance measurement and has a positive effect on credit scoring. Further, companies should focus on their main activities and obtain a significant portion of their profit from these activities. SMEs should apply more transparent fiscal policies when conducting and reporting their activities, and they should prepare their financial statements more accurately in order to obtain better credibility. Shareholders' paying performance is one of the most significant evaluation criteria, SME shareholders should be careful about their payment records.

The first limitation of the study is, the number of evaluated credit rating systems, that is, only one credit scoring system used by a credit institution in Turkey is evaluated. Secondly, only 17 independent variables, despite there are various other factors affecting credit scores, were chosen for this study. More generalizable results can be obtained by increasing the number of samples and credit institutions. Each credit institution applies different credit policies in their credit scoring systems. These policies may differ due to many factors. As the literature review shows, there were not many studies that can help SMEs determine their credit scores. For most credit institutions, the credit policies applied in credit rating systems are not openly shared to prevent the risk that companies manipulate the results. It is therefore hard to obtain data from these corporations and similar studies in the literature have been forced to rely on limited data or limited coverage. Nevertheless, this study has offered valuable suggestions to SMEs to consider in their credit applications. Similar future studies can make valuable contributions to literature by increasing the number of credit institutions, samples and variables analyzed. 


\section{REFERENCES}

Abdou, A. H. (2009). Genetic programming for credit scoring: The case of Egyptian public sector banks. Expert Systems with Applications (36), p. 1140211417.

Akgemici, T. (2001). Kobilerin Temel Sorunlari ve Saglanan Destekler. Ankara: T.C. Sanayi ve Ticaret Bakanligi, KOSGEB Kucuk ve Orta Olcekli Sanayi Gelistirme ve Destekleme Idaresi Baskanligi.

Aksumer, S. KOBI'lerin Ekonomideki Yeri, Yapisal Sorunlari Ve Cozum Onerileri, Konya Ticaret Odasi, Ekonomik Arastirmalar ve Proje Mudurlugu, Turkiye, 2015, http://www.kto.org.tr/d/file/kobi\%E2\%80\%99lerin -ekonomideki-yeri-ve-yapisal-sorunlari.pdf, accessed on 11/03/2018.

Altman, E. I., Esentato, M., \& Sabato, G. (2018). Assessing the credit worthiness of Italian SMEs and mini-bond issuers. Global Finance Journal.

Ay, H.M., Talasli; E., Turkiye'de Kobi'lerin Ihracattaki Yeri ve Karsilastiklari Sorunlar, Selcuk Universitesi Karaman I.I.B.F.Dergisi Yerel Ekonomiler Ozel Sayisi, pp.173-184, May, 2007

Babuscu. S. \& Hazar, A. (2008). SPK Kredi Derecelendirme Uzmanligi Sinavlarina Hazirlik. Ankara, 360-362.

Bekhet, H. A. \& Eletter, S. F. K. (2014). Credit risk assessment model for Jordanian commercial banks: Neuralscoring approach. Review of Development Finance (4), p. 20-28.

Belas, J., Mišanková, M., Schönfeld, J., \& Gavurová, B. (2017). Credit Risk Management: Financial Safety and Sustainability Aspects. Journal of Security \& Sustainability Issues, 7(1).

Bingol, B. (2009). Turkiye'de KOBI Niteliginde Faaliyet Gosteren Tekstil Isletmelerinin Basel II Kriterleri Cercevesinde Kredi Derecelendirme Metodolojisi Uygulamasi. Unpublished PHD Thesis, Marmara Universitesi.

Bluhm, C., Overbeck, L. and Wagner, C. (2003). An Introduction to Credit Risk Modeling. Boca Raton, Florida: CRC Press Company.

Cansiz, M. (2008). Turkiye'de KOBI'ler ve KOSGEB. Ankara: T.C. Basbakanlik Devlet Planlama Teskilati (DPT). p.3

Dinh, T.H.T. \& Kleimeier, S. (2007). A credit scoring model for Vietnam's retail banking market. International Review of Financial Analysis (16), p. 471-495.

Emel A. B., Oral, N., Reisman, A. and Yolalan, R. (2003). A Credit Scoring Approach for the Commercial
Banking Sector. Socio-Economic Planning Sciences (37), p. 103-123.

Higgins, J. (2005). Introduction to Multiple Regression (Chp4). The Radical Statistician, p.1-15.

Jacobson, T. \& Roszbach, K. (2003). Bank Lending Policy, Credit Scoring and Value-at-Risk. Journal of Banking \& Finance (27), p. 615-633.

Joseph, F. H. et al. (2010). Multivariate Data Analysis (7 $7^{\text {th }}$ ed.). Pearson Prentice Hall.

Louzada, F., Silva, P. H. F. and Diniz, C. A. R. (2012). On the impact of disproportional samples in credit scoring models: An application to a Brazilian bank data. Expert Systems with Applications (39), p. 8071-8078.

Marron, D. (2007). 'Lending by numbers': credit scoring and the constitution of risk within American consumer credit. Economy and society, 36(1), 103-133.

Marshall, A., Tang, L. and Milne, A. (2010). Variable reduction, sample selection bias and bank retail credit scoring. Journal of Empirical Finance (17), p. 501-512.

Min, J. H. \& Lee, Y. (2008). A Practical Approach to Credit Scoring. Expert Systems with Applications (35), p. 1762-1770.

Muftuoglu, T. M. (2002). Turkiye'de Kucuk ve Orta Olcekli Isletmeler Sorunlar Oneriler (5th ed.). Ankara, p.30-31.

Ono, A., Hasumi, R., and Hirata, H. (2014). Differentiated use of small business credit scoring by relationship lenders and transactional lenders: Evidence from firm bank matched data in Japan. Journal of Banking \& Finance (42), p.371-380.

Sezgin, O. (2006). Statistical Methods of Credit Rating. Unpublished Master's Thesis, The Middle East Technical University.

Sirvan, N. (2004). Kredi Derecelendirme ve Turkiye Ekonomisi. https://www.researchgate.net/publication/267771881_KREDI_DERECELENDIRME_VE_ TURKIYE_EKONOMISI, accessed on 06/10/2016.

The New Basel Capital Accord: An explanatory note (2001). https://www.bis.org/publ/bcbsca01.pdf, accessed on 10/12/2017.

Vurur, N. S. Y. (2009). Basel Uzlasisi Cercevesinde Kobilerde Kredi Derecelendirme Notu Uygulamasi. Unpublished PHD Thesis, Afyon Kocatepe Universitesi.

Zhang, M., He, Y. and Zhou, Z. (2013). Study on the Influence Factors of High-tech Enterprise Credit Risk: Empirical Evidence From China's Listed Companies. Procedia Computer Science (17), p. 901-910. 